\title{
Induction of spermatogenic cell apoptosis in prepubertal rat testes irrespective of testicular steroidogenesis: a possible estrogenic effect of di(n-butyl) phthalate
}

\author{
Mohammad Shah Alam, Seiichiroh Ohsako', Takashi Matsuwaki ${ }^{2}$, Xiao Bo Zhu, \\ Naoki Tsunekawa, Yoshiakira Kanai, Hideko Sone ${ }^{3}$, Chiharu Tohyama ${ }^{1}$ \\ and Masamichi Kurohmaru
}

Department of Veterinary Anatomy, Graduate School of Agricultural and Life Sciences, The University of Tokyo, 1-1-1
Yayoi, Bunkyo-ku, Tokyo 113-8657, Japan, ${ }^{1}$ Laboratory of Environmental Health Sciences, Graduate School and
Faculty of Medicine, Center for Disease Biology and Integrative Medicine, The University of Tokyo, 7-3-1 Hongo,
Bunkyo-Ku, Tokyo 113-0033, Japan, ${ }^{2}$ Department of Veterinary Physiology, Graduate School of Agricultural and Life
Sciences, The University of Tokyo, 1-1-1 Yayoi, Bunkyo-ku, Tokyo 113-8657, Japan and ${ }^{3}$ Research Center for
Environmental Risk, National Institute of Environmental Studies, 16-2 Onogawa, Tsukuba, Ibaraki 503-8506, Japan

Correspondence should be addressed to M Kurohmaru; Email: amkuroh@mail.ecc.u-tokyo.ac.jp

\begin{abstract}
Although di(n-butyl) phthalate (DBP), a suspected endocrine disruptor, induces testicular atrophy in prepubertal male rats, whether it exerts estrogenic activity in vivo remains a matter of debate. In the present study, we explored the estrogenic potency of DBP using 3-week-old male rats, and then examined the relationship between estrogen-induced spermatogenic cell apoptosis and testicular steroidogenesis. Daily exposure to DBP for 7 days caused testicular atrophy due to loss of spermatogenic cells, whereas testicular steroidogenesis was almost the same with the control values. A single exposure of DBP decreased testicular steroidogenesis in addition to decreasing the level of serum LH at $3 \mathrm{~h}$ after DBP treatment, with an extremely high incidence of apoptotic spermatogenic cells at $6 \mathrm{~h}$ after administration. To elucidate the estrogenic activity of DBP, we carried out an inhibition study using pure antiestrogen ICI 182,780 (ICI) in a model of spermatogenic cell apoptosis induced by DBP or estradial-3-benzoate (EB). Although both the DBP- and EB-treated groups showed a significant increase in spermatogenic cell apoptosis, ICI pretreatment significantly decreased the number of apoptotic spermatogenic cells in these two groups. In contrast, testicular steroidogenesis and serum FSH were significantly reduced in all the treated groups, even in the DBP + ICI and EB + ICI groups. Taken together, these findings led us to conclude that estrogenic compounds such as DBP and EB induce spermatogenic cell apoptosis in prepubertal rats, probably by activating estrogen receptors in testis, and that reduction in testicular steroidogenic function induced by estrogenic compounds is not associated with spermatogenic cell apoptosis. Reproduction (2010) 139 427-437
\end{abstract}

\section{Introduction}

Di(n-butyl) phthalate (DBP) is one of the most widely studied phthalate esters that disrupt the growth of normal reproductive organs, because of its wide use as a plasticizer in cosmetics, printing inks, and pharmaceutical coatings. The most prominent effect of DBP is testicular atrophy (Oishi \& Hiraga 1980, Gray et al. 1982). To date, several mechanisms have been proposed to explain the induction of testicular atrophy by DBP, such as the depletion of zinc (Oishi \& Hiraga 1980), increased oxidative damage of proteins, lipids, and DNA (Fukuoka et al. 1990), alteration of vimentin cytoskeleton organization (Kleymenova et al. 2005), or membrane alteration in Sertoli cells leading to sloughing of spermatogenic cells (Kleymenova et al. 2005).
However, the cellular target of DBP and molecular mechanisms of DBP-induced spermatogenic cell apoptosis remain to be unknown.

The study on serum levels of DBP in thelarche patients (a premature breast development before age 8) showed that 28 of $41(68 \%)$ thelarche patients displayed significantly higher $(15-276 \mathrm{mg} / \mathrm{l})$ levels of DBP (Colon et al. 2000). The high-serum level of DBP in thelarche patients is a matter of concern as an estrogenic xenobiotic. DBP and butyl benzyl phthalate were found to be capable of binding to estrogen receptor $\alpha(E R \alpha)$ and then enhancing the proliferation of MCF-7 human breast cancer cells expressing ER $\alpha$ (Jobling et al. 1995, Harris et al. 1997, Zacharewski et al. 1998, Nishihara et al. 2000). In addition, DBP has been shown to exhibit an 
estrogenicity in an E-screen assay (Soto et al. 1995, Hong et al. 2005) and to prevent tamoxifen, an ER antagonist, from inducing apoptosis in MCF-7 cells (Kim et al. 2004). In contrast, phthalate esters including DBP displayed no biological activity in a rat uterotrophic assay, an in vivo screening test for estrogenicity (Milligan et al. 1998, Zacharewski et al. 1998). Therefore, the specific cellular target of DBP is still a matter of debate.

The role of estrogen in spermatogenesis has been reported that estrogen is essential for spermatogenesis (Eddy et al. 1996, O'Donnell et al. 2001), spermatogenic cells express ERs (Saunders et al. 1998, O'Donnell et al. 2001), and estrogen-like chemicals present in the environment adversely affect male reproductive health (Akingbemi \& Hardy 2001). Such chemicals have the ability to affect gene expression and cellular function by binding to hormone receptors (Hall \& Korach 2002). It is generally accepted that the hypothalamo-pituitarygonadal (HPG) axis regulates spermatogenesis by controlling circulating levels of LH through the feedback regulation of steroid hormones, and this feedback loop can be intercepted by endocrine-disrupting chemicals (EDCs) binding to ERs in hypothalamus. Direct interference to spermatogenic cells is also possible, because these cells are known to express ERs (Saunders et al. 1998, 2002). Adult male hamsters given diethylstilbestrol showed a significant decrease in gonadotropin levels, leading to the increased spermatogenic cell apoptosis through the suppression of testosterone level (Nonclercq et al. 1996). In another study, administration of a single high dose of estradial-3-benzoate (EB) to 1-day-old male rats causes a reduction in $\mathrm{GnRH}$ secretion, resulting in the suppression of circulating level of $\mathrm{LH}$ and consequently testosterone (Tena-Sempere et al. 2000). Estrogen is directly involved in the suppression of testicular ER expression (Tena-Sempere et al. 2000). Therefore, we hypothesize that ERs present in testes may have a role in the induction of spermatogenic cell apoptosis by estrogenic compounds.

ICI 182,780 (ICI), a pure estrogen antagonist, binds to both $E R \alpha$ and $E R \beta$ (Kuiper et al. 1998, Howell et al. 2000), does not cross the blood-brain barrier (Wade et al. 1993), and is currently used as a first choice treatment for human breast cancer, because of its local peripheral action (Wiebe et al. 1993). In the present study, in order to reveal the estrogenicity of DBP, attempts were made to block the ERs on prepubertal rat testes with $\mathrm{ICl}$ prior to DBP or EB administration.

\section{Results \\ Effects of repeated DBP exposure on testis morphology and testicular steroidogenesis}

Daily administration of DBP for 7 days resulted in a significant decrease of testis weight in a dose-dependent manner (Fig. 1A). In histological observations, the most common lesion site was a seminiferous tubule. Lesions in seminiferous tubules were characterized by decreased tubular size, depletion of spermatogenic cells, wider tubular lumen, and ultimately a thin layer of seminiferous tubules depending on the dose. Detachment of spermatogenic cells, reduction in diameter of tubular size, and giant cells with cellular debris in tubular lumen were frequently observed in the group treated with $500 \mathrm{mg} / \mathrm{kg}$ per day DBP (Fig. 1D), while complete loss of spermatocytes in seminiferous tubules was seen in the group treated with $1000 \mathrm{mg} / \mathrm{kg}$ per day DBP, leading to irregularly shaped and sized tubules (Fig. 1E). We performed a TUNEL assay to examine whether degraded spermatogenic cells were undergoing apoptosis. A significant number of apoptotic (TUNEL-positive) spermatogenic cells were detected in the $500 \mathrm{mg} / \mathrm{kg}$ per day group (Fig. 1H) as compared with the control (Fig. 1F). In the $1000 \mathrm{mg} / \mathrm{kg}$ per day group, only a few apoptotic spermatogenic cells were found due to the complete loss of spermatocytes (Fig. 1I). The number of apoptotic cells per seminiferous tubule was higher in the $500 \mathrm{mg} / \mathrm{kg}$ per day group than in the $250 \mathrm{mg} / \mathrm{kg}$ per day group.

To examine the possible involvement of testicular steroidogenesis in spermatogenic cell apoptosis, the ultrastructure of Leydig cells was observed by transmission electron microscopy, and intratesticular testosterone (ITT) levels were analyzed by testosterone EIA assay. We selected $500 \mathrm{mg} \mathrm{DBP} / \mathrm{kg}$ per day as a representative dose, based on the above observation. Several lipid droplets in the Leydig cell cytoplasm were distinctly observed in the treated group, whereas these droplets were not found in the control group (Fig. 2A and $\mathrm{B}$ ). The average ITT concentration of the DBP-treated groups was almost the same with that of the control group (Fig. 2C). The mRNA expression levels of four steroidogenic enzymes were also analyzed by real-time RT-PCR. Although statistical significance was not detected, DBP exposure apparently increased the cytochrome P450 side chain cleavage (P450scC, Cyp11a1) and $3 \beta$ hydroxysteroid dehydrogenase $(3 \beta H s d, H s d 3 b)$ expressions (Fig. 2D and F). The cytochrome P450 17 $\alpha / \mathrm{C}_{17-20}$ lyase (P450c17, Cyp17a1) and $17 \beta$ hydroxysteroid dehydrogenase (17 $\beta \mathrm{H} s d, \mathrm{Hsd} 17 \mathrm{~b})$ expressions in the DBP-treated groups were almost the same with that of the control group (Fig. 2E and G). These findings indicate that the testes after daily exposure of DBP for 7 days shows normal or slightly enhanced steroidogenesis with a high rate of seminiferous tubule disruption.

\section{Effects of an acute single exposure of DBP on spermatogenic cell apoptosis and testicular steroidogenesis}

In a 7-day daily exposure of DBP, seminiferous tubules showed a depletion of spermatogenic cells, probably due to apoptosis. In order to determine the exact time point of maximum apoptosis and the exact target cell 
type for DBP insult, we conducted a time-course study with exposure times of 3,6 , and $24 \mathrm{~h}$ after a single exposure of DBP. We found a significant increase in the number of apoptotic spermatogenic cells in the treated groups in comparison with the control (Fig. 3A-D). The maximal number of apoptotic spermatogenic cells was detected at $6 \mathrm{~h}$ after treatment (Fig. 3C and J).
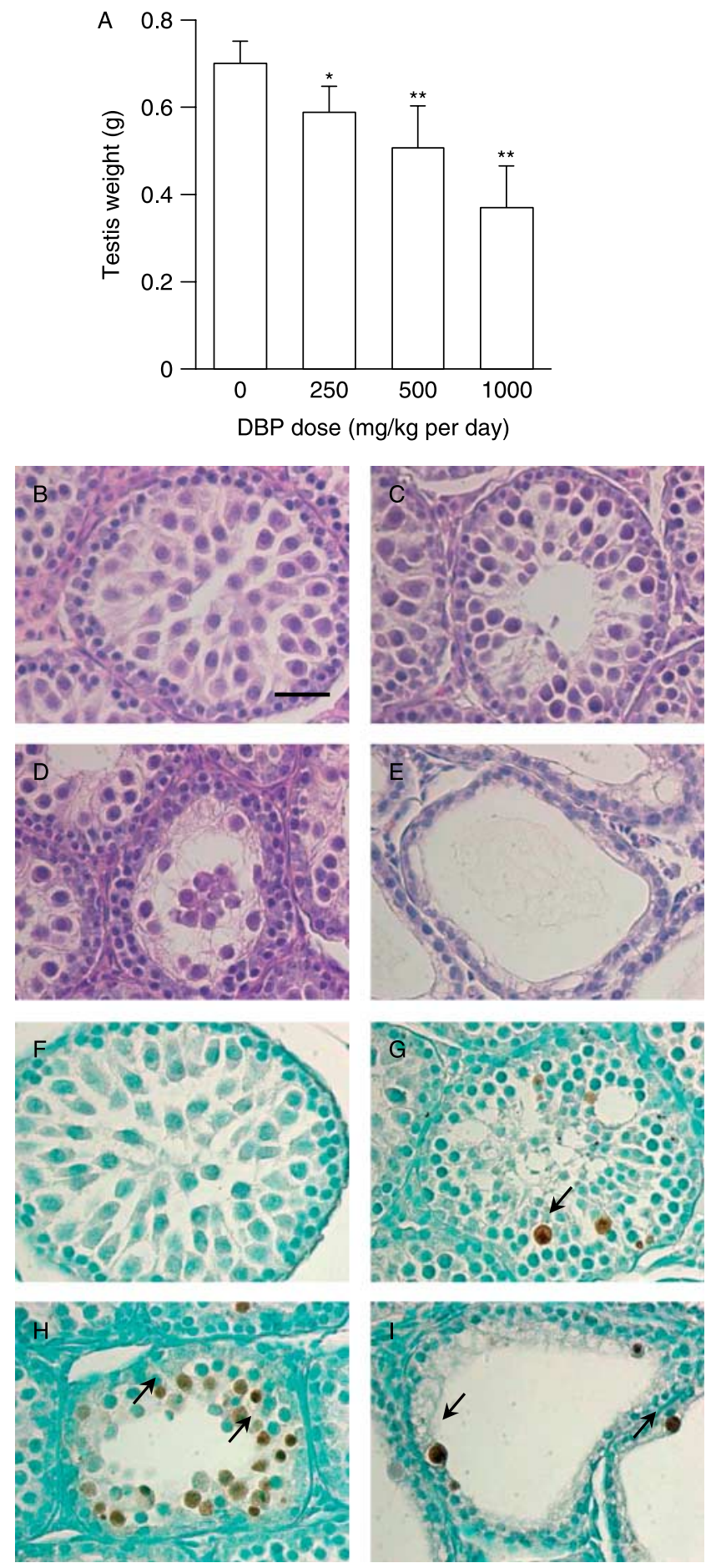

At $24 \mathrm{~h}$ after administration, the number of apoptotic cells began to gradually decline, although it was still significantly greater than that in the control group (Fig. 3J).

In order to evaluate the spermatogenic cell types that underwent apoptosis, apoptotic cells were analyzed by light and transmission electron microscopies. At the light microscopic level, apoptotic cells were identified by their prominent basophilia and shrinkage of both cytoplasm and nucleus. Spermatocytes were the largest cells and showed typically dispersed chromatin, and spermatogonia were identified by their location (Fig. $3 \mathrm{~F}$ and G). Similarly, at the electron microscopic level, apoptotic spermatocytes with chromatin clumping and shrinkage of cytoplasm and nucleus were clearly distinguishable (Fig. $3 \mathrm{H}$ and $\mathrm{I}$ ).

ITT level was also measured by a testosterone EIA assay. In contrast to 7-day daily exposure, a single exposure of DBP $(500 \mathrm{mg} / \mathrm{kg})$ significantly decreased the level of ITT (Fig. 4A). To address whether DBP suppressed the ITT level by affecting the HPG axis, we analyzed the serum LH level by RIA. Inhibition of testicular testosterone production by estrogen administration is mediated by a decrease in serum LH level through the action of estrogen on the hypothalamopituitary axis (Jong et al. 1975). As shown in Fig. 4B, the serum $\mathrm{LH}$ concentration showed a tendency to decrease $(P=0.06)$ in the DBP-treated groups, especially at $3 \mathrm{~h}$ after DBP administration. These data suggested that DBP might have blocked LH secretion shortly after administration, probably due to estrogenic activity in hypothalamus, and then diminished the stimulation of Leydig cells, thereby reducing the production of testosterone (Fig. 4). Real-time RT-PCR analysis also showed a statistically significant reduction in Cyp11a1, Cyp17a1, Hsd3b, and Hsd17b expressions by DBP treatment (Fig. 4C-F). The decrease in ITT nearly paralleled the decrease in the mRNA levels of all testicular steroidogenic enzymes (Cyp11a1, Cyp17a1, $H s d 3 b$, and $H s d 17 b)$. These results illustrated that DBP decreased testicular steroidogenesis and that this decrease likely occurred via suppression of the HPG axis, suggesting that DBP acts as an estrogen agonist.

\footnotetext{
Figure 1 Effects of repeated DBP exposure on testis morphology. Testis weight after once daily administration of DBP for 7 days $(A)$ is shown. Results are expressed as the means \pm S.E.M. $(n=6)$. Statistically significant differences were determined by ANOVA followed by Fisher's PLSD test $\left({ }^{*} P<0.05 ; * * P<0.01\right.$ versus control). Histological changes of testes after once daily administration of DBP for 7 days are shown using hematoxylin and eosin staining (B-E) and TUNEL labeling $(\mathrm{F}-\mathrm{I})$. Results are shown for the vehicle-treated (B), $250 \mathrm{mg} / \mathrm{kg}$ per day (C), $500 \mathrm{mg} / \mathrm{kg}$ per day (D), and $1000 \mathrm{mg} / \mathrm{kg}$ per day (E) groups. Note the reduction in diameter and irregularly shaped seminiferous tubules due to depletion of spermatogenic cells. TUNEL-positive (apoptotic) spermatogenic cells are indicated by arrows in testes. Vehicle-treated control (F), $250 \mathrm{mg} / \mathrm{kg}$ per day (G), $500 \mathrm{mg} / \mathrm{kg}$ per day $(\mathrm{H})$, and $1000 \mathrm{mg} / \mathrm{kg}$ per day (I) treated groups. Scale bar, $20 \mu \mathrm{m}$.
} 

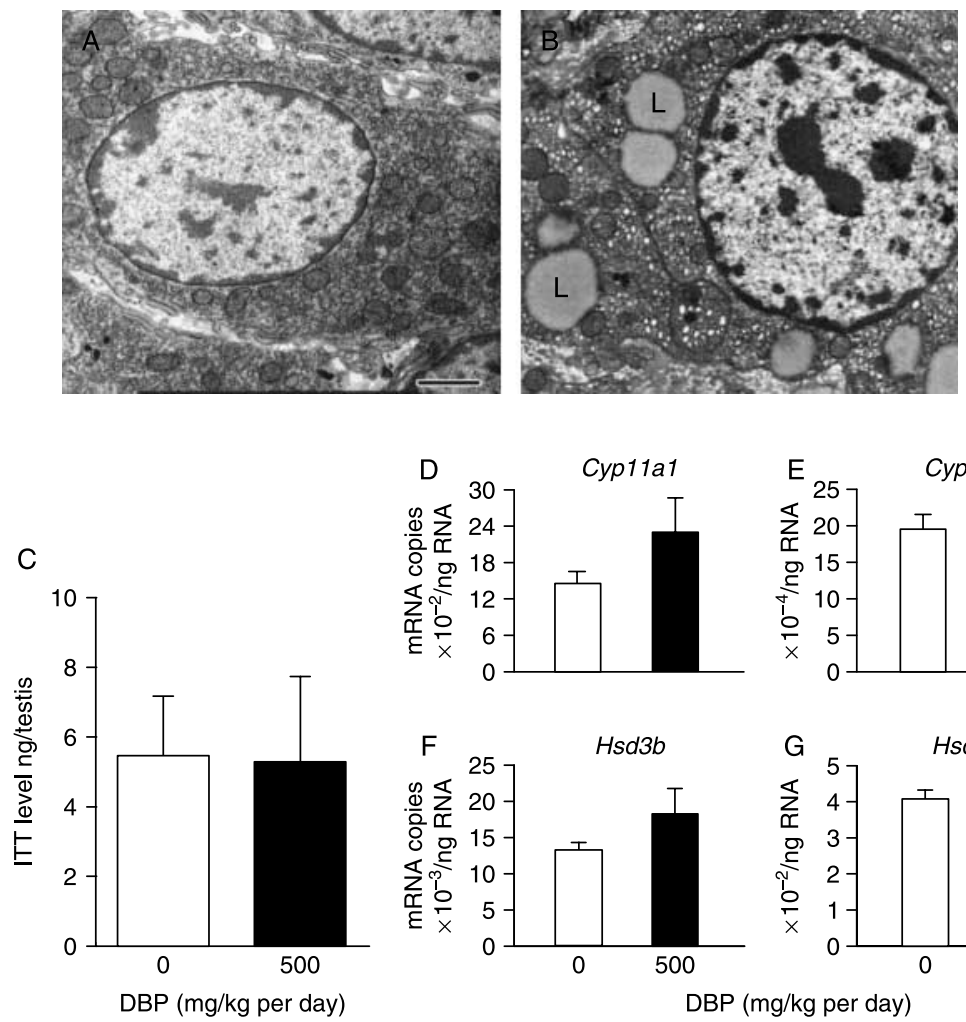
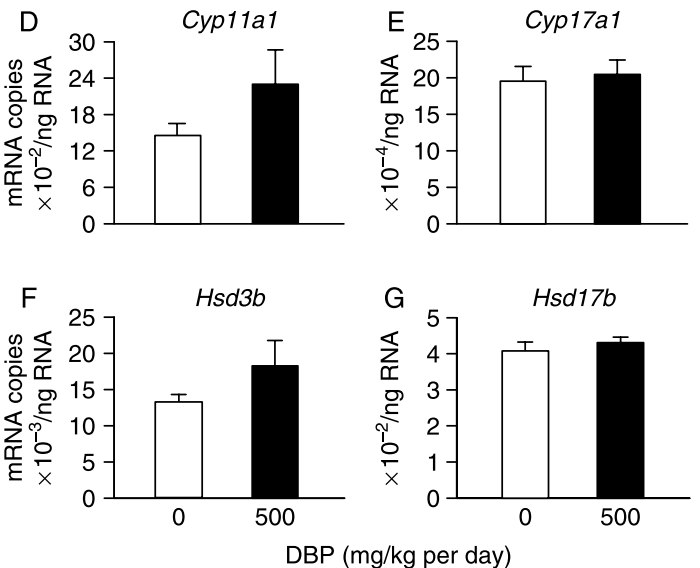

\begin{abstract}
Figure 2 Effects of repeated DBP exposure on testicular steroidogenesis. Ultrastructural changes in Leydig cells of the control (A) and $500 \mathrm{mg} / \mathrm{kg}$ per day treated groups (B). L indicates lipid droplets. Scale bar, $1 \mu \mathrm{m}$. Intratesticular testosterone (ITT) level (C) and testicular mRNA expressions for Cyp11a1 (D), Cyp17a1 (E), $H s d 3 b(\mathrm{~F})$, and Hsd17b (G). ITT level was measured by testosterone EIA assay, and mRNA expressions of testicular steroidogenic enzymes were determined by real-time RT-PCR. Results are expressed as the means \pm S.E.M. $(n=8$ for ITT and $n=3$ for testicular steroidogenic enzymes mRNA expressions). Statistically significant differences between means from the control and treated groups were determined by Student's $t$-test.
\end{abstract}

\section{Antiestrogen ICI inhibited DBP- or EB-induced spermatogenic cell apoptosis}

A single exposure of DBP resulted in decreased testicular steroidogenesis by suppression of LH level together with increased spermatogenic cell apoptosis. To examine the hypothesis that spermatogenic cell apoptosis is induced by estrogenic compounds through ERs, we further conducted an inhibition study with pure antiestrogen $\mathrm{ICl}$. The effect of EB, a synthetic long-term acting estrogen which is converted to $17 \beta$-estradiol $\left(E_{2}\right)$ in liver, was examined using male rats of the same age. As shown in Fig. 5B, $500 \mathrm{mg} / \mathrm{kg}$ of DBP significantly increased $(P<0.001)$ the number of apoptotic spermatogenic cells compared with that in the control. Treatment with $200 \mu \mathrm{g} / \mathrm{kg}$ EB also significantly increased $(P<0.001)$ the number of apoptotic spermatogenic cells as compared with that in the control group, although the number of apoptotic spermatogenic cells in the EB-treated group was lower than that in the DBP-treated group (Fig. 5D). In the rats treated with the above doses of DBP and $\mathrm{EB}$, pretreatment with $\mathrm{ICl}$ decreased $(P<0.001)$ the apoptotic spermatogenic cell number compared with that in the groups without pretreatment (Fig. 5C, E, and G).

\section{Comparison of the effects of DBP and EB on testicular steroidogenesis and serum FSH level}

In order to examine the possible correlation between inhibition of DBP- or EB-induced spermatogenic cell apoptosis by $\mathrm{ICl}$ and testicular steroidogenesis, the testicular steroidogenic capacity was examined in the samples obtained from the above inhibition study (Fig. 5). It is known that testosterone withdrawal results in spermatogenic cell apoptosis (Blanco-Rodriguez \& Martinez-Garcia 1997, 1998, Creasy 2001, McLachlan et al. 2002). In our study, a single exposure of DBP caused a significant reduction in ITT as well as testicular steroidogenic enzymes expressions (Fig. 4). Therefore, we further examined whether $\mathrm{ICI}$ pretreatment would inhibit the reduction in testicular steroidogenesis induced by DBP or EB. However, ITT level was significantly lower in the $\mathrm{DBP}+\mathrm{ICl}-(P<0.001)$ or $\mathrm{EB}+\mathrm{ICl}-(P=0.001)$ treated group compared with that in the intact and control groups. The level in the pretreated groups was similar to that in the group treated with DBP $(P<0.001)$ or EB $(P<0.001)$ alone (Fig. 6A). The serum FSH level was also measured in the samples obtained from the above inhibition study (Fig. 5) to correlate between the apoptotic index and testicular steroidogenesis (Figs 5 and 6). The serum FSH level was significantly decreased in the DBP- $(P<0.001)$ and EB$(P<0.001)$ treated groups. These levels in the pretreated groups were similar to those in the groups without pretreatment respectively (Fig. 7). Similarly, the mRNA levels of Cyp11a1, Cyp17a1, Hsd3b, and Hsd17b were also significantly decreased in the DBP, EB, DBP $+\mathrm{ICl}$, and $\mathrm{EB}+\mathrm{ICl}$ groups compared with those in the control and intact groups (Fig. 6B-E), whereas no significant 


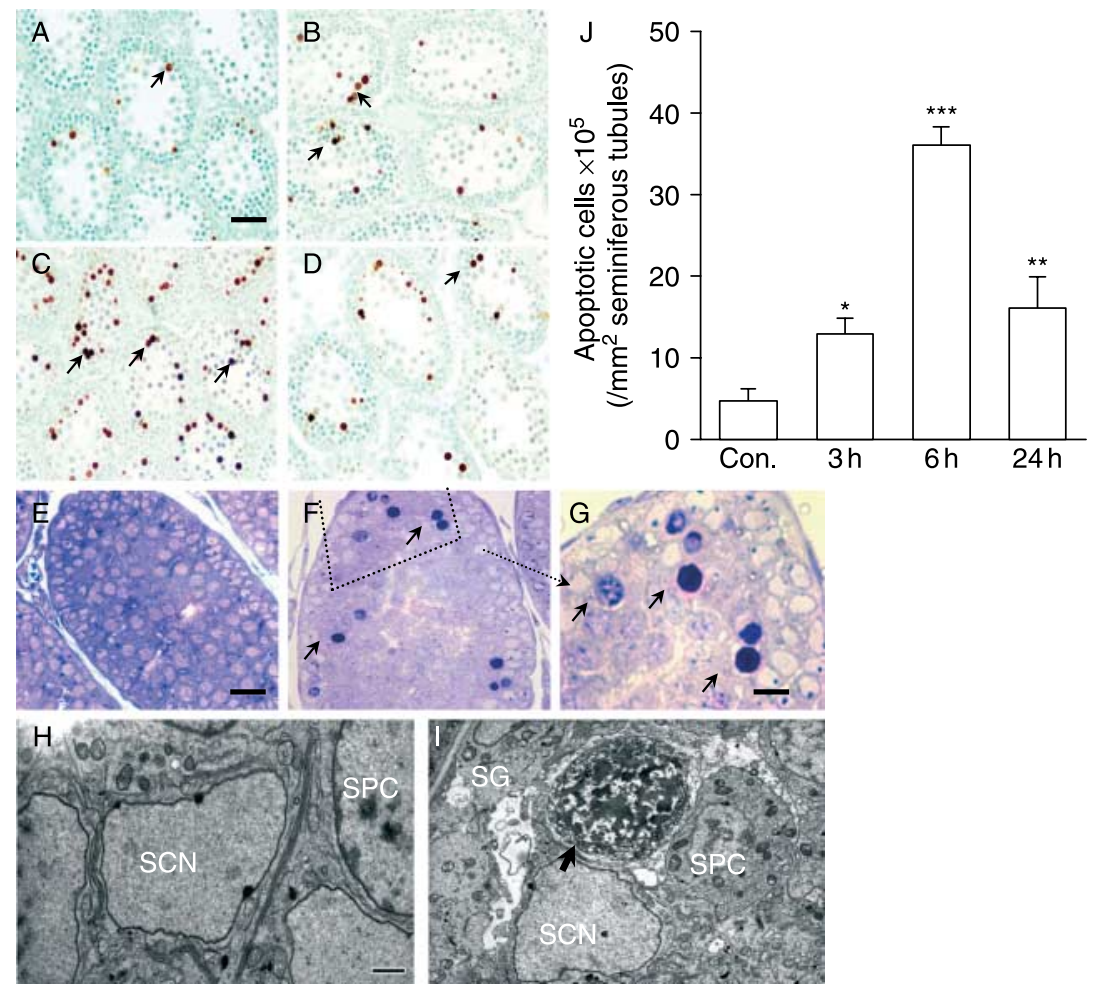

Figure 3 Spermatocytes apoptosis after a single exposure of $500 \mathrm{mg}$ DBP/kg. TUNEL labeling of testes. Vehicle-treated control (A), and at $3 \mathrm{~h}$ (B), at $6 \mathrm{~h}(\mathrm{C})$, and at $24 \mathrm{~h}(\mathrm{D})$ after treatment. Note the maximal apoptotic spermatogenic cell number at $6 \mathrm{~h}$ after treatment. Arrows indicate apoptotic spermatocytes. Scale bar, $50 \mu \mathrm{m}$. Semi-thin sections of seminiferous tubules of the control $(\mathrm{E})$, and at $6 \mathrm{~h}(\mathrm{~F}$ and $\mathrm{G})$ after treatment. Toluidine blue staining. E-F, scale bar, $20 \mu \mathrm{m}$. $\mathrm{G}$, scale bar, $10 \mu \mathrm{m}$. Transmission electron micrographs of control $(\mathrm{H})$ and at $6 \mathrm{~h}(\mathrm{I})$ after treatment. Arrowhead, apoptotic spermatocyte; $\mathrm{SCN}$, Sertoli cell nucleus; SG, spermatogonium; SPC, spermatocyte. Scale bar, $1 \mu \mathrm{m}$. Quantification of apoptotic spermatogenic cells (J). Values representing the number of apoptotic cells per $1 \mathrm{~mm}^{2}$ seminiferous tubules areas are expressed as the means \pm S.E.M. $(n=8)$. Statistically significant differences were determined by ANOVA followed by Fisher's PLSD test $\left({ }^{*} P<0.5\right.$, $* * P<0.01, * * * P<0.001$ versus control).

changes of ITT concentration, serum FSH level, and steroidogenic enzymes expressions were found in the $\mathrm{ICl}$ alone-treated group compared with those in the intact and vehicle groups.

\section{Discussion}

\section{Repeated DBP exposure causes testicular atrophy without significant changes in testicular steroidogenesis}

The present study demonstrated that repeated administration of DBP for 7 days increased the number of disrupted seminiferous tubules with spermatogenic cell depletion. Disturbance in seminiferous tubules and enhanced testicular steroidogenesis have been reported in prepubertal rats chronically exposed to DBP (Ryu et al. 2007). In our study, however, there was no significant change in testicular steroidogenesis, although excess lipid droplets were clearly observed in Leydig cells. The discrepancy in testosterone level between this study and Ryu et al. (2007) may be due to the difference in exposure period (7 vs 30 days). Our study, however, showed a similar level of disrupted seminiferous tubules to that by Ryu et al. (2007), indicating that testosterone production may not be associated with testicular atrophy induced by DBP.

\section{Acute DBP exposure increases spermatogenic cell apoptosis and decreases testicular steroidogenesis}

It is well established that testosterone synthesis is controlled by negative feedback regulation of HPG axis, and an increase in testosterone level causes a reduction in LH secretion from pituitary by activating androgen receptor (AR) in hypothalamus. A testosterone metabolite by aromatization, $\mathrm{E}_{2}$, can also reduce $\mathrm{LH}$ secretion by binding to ERs in hypothalamus as well as androgens. Then, a subsequent reduction in $\mathrm{LH}$ pulse would lead to a suppression of testosterone production. Decreased testicular testosterone biosynthesis as well as decreased serum LH level and serum FSH level occurs after exogenous estrogen exposure, together with increased spermatogenic cell apoptosis (D'Souza et al. 2005). To our knowledge, the present study reveals for the first time that DBP suppresses testicular steroidogenesis with a correspondent decrease in serum FSH (Fig. 7) and serum LH level (Fig. 4B) shortly after treatment, probably by interacting with ERs in hypothalamus. In addition, the similar reduction in serum $\mathrm{FSH}$ level was found in the EB-treated group (Fig. 7). All of the data indicate that phthalate ester has an estrogenicity similar to that of $E_{2}$.

It is well established that testosterone synthesis depends on the frequency and amplitude of LH pulse, and disruption of $\mathrm{LH}$ pulse by administration of estrogen has been shown to cause the suppression of testosterone 

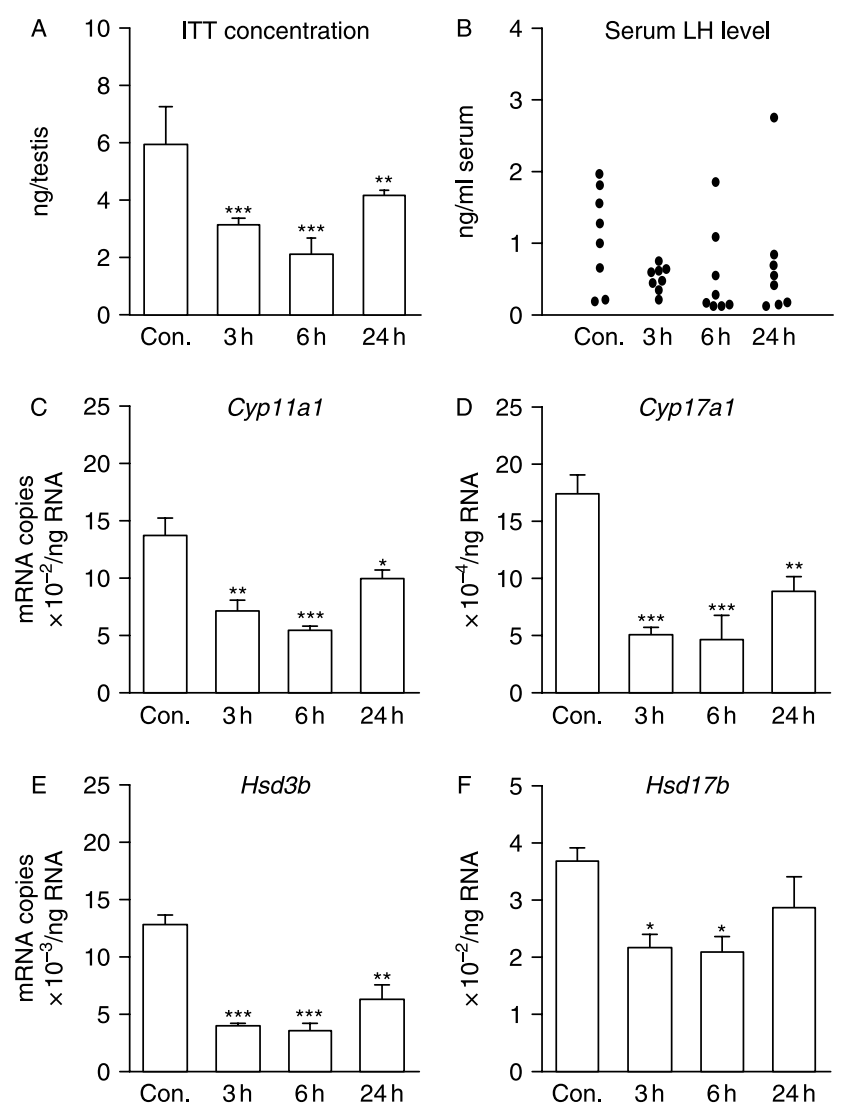

Figure 4 Testicular steroidogenesis and serum $\mathrm{LH}$ levels after a single exposure of $500 \mathrm{mg}$ DBP/kg. Intratesticular testosterone (ITT) level (A), serum LH level (B), and testicular mRNA expressions for Cyp11a1 (C), Cyp17a1 (D), Hsd3b (E), and Hsd17b (F). ITT level was measured by testosterone EIA assay, serum LH was measured by RIA, and mRNA expressions of testicular steroidogenic enzymes were analyzed by real-time RT-PCR. Note that the decreased serum LH pulse led to a reduction in ITT level as well as a decrease in mRNA expressions in the treated rats. Results are expressed as the means \pm s.E.M. ( $n=8$ for ITT and serum $\mathrm{LH}$, and $n=3$ for real-time RT-PCR). Statistically significant differences were determined by ANOVA followed by Fisher's PLSD test $\left({ }^{*} P<0.05 ;{ }^{* *} P<0.01,{ }^{* * *} P<0.001\right.$ versus control).

production (McGarvey et al. 2001). To demonstrate the effects of DBP on LH pulsatility, the serial blood sampling at several minute intervals from live animals and the appropriate pulse analysis should be required. But, this is difficult to detect in the present study because of a single spot blood sample. DBP might induce disruption of $\mathrm{LH}$ pulse and subsequently decrease testicular testosterone production. On this point, further studies are required in the future.

\section{DBP-induced spermatogenic cell apoptosis is mediated via ERs}

There is much evidence that DBP can interact with ERs. For example, several studies employing an ER-mediated yeast growth assay or a reporter assay with human breast cancer cell line MCF-7 have demonstrated the interaction between DBP and ERs (Jobling et al. 1995, Harris et al. 1997, Zacharewski et al. 1998, Andersen et al. 1999). Moreover, DBP exhibited an estrogenicity in an E-screen assay (Soto et al. 1995) and prevented tamoxifen (ER antagonist)-induced apoptosis in MCF-7 cells (Kim et al. 2004). However, it is still unclear whether DBP has an estrogenicity in an in vivo experimental model, because any phthalate esters, including DBP, displayed no significant changes in the female reproductive organ weight in the rat uterotrophic assay (Milligan et al. 1998, Zacharewski et al. 1998). In the present study, decreased testicular steroidogenesis was observed in a single exposure of DBP with the same spectrum of those of the EB-treated groups (Fig. 6). Administration of synthetic estrogens, including $E B$, is known to induce spermatogenic cell apoptosis. Here, for the first time, we have demonstrated that pure antiestrogen $\mathrm{ICl}$ inhibited EB-induced spermatogenic cell apoptosis. Similarly, DBP-induced spermatogenic cell apoptosis was significantly decreased by $\mathrm{ICI}$ pretreatment (Fig. 5), clearly demonstrating that, at least in immature male rats, DBP acts as an estrogen agonist. To our knowledge, this is the first report using an in vivo model to demonstrate the estrogenicity of DBP through ERs.

EB- and DBP-induced spermatogenic cell apoptosis was blocked by pretreatment with an ER antagonist, $\mathrm{ICl}$, indicating that $E_{2}$ as well as DBP was functioning through ERs. Indeed, both receptors are present in testes (Saunders et al. 1998, Pelletier et al. 2000). In general, the classic ER-signaling pathway involves the binding of the ligand-bound ERs (either $\alpha$ or $\beta$ ) to the estrogenresponsive element (ERE) that regulates transcription of target genes. However, ERs also mediate gene transcription by binding to an AP-1 element together with the transcription factors, Fos and Jun (McEwen \& Alves 1999). $E R \alpha$ and $E R \beta$ have been shown to transcript in opposite ways from the AP- 1 site; when bound to $E_{2}$, ER $\alpha$ activates and ER $\beta$ inhibits transcription (Paech et al. 1997). In contrast to the endogenous estrogen, antiestrogens, including raloxifene, and $\mathrm{ICl}$ have been shown to effectively activate transcription from an AP-1 site when bound to ER $\beta$ (Paech et al. 1997). The intracellular mechanisms of ERs action in the present study and the possible involvement of both ER $\alpha$ and $E R \beta$ in spermatogenic cell apoptosis are not known, and further studies are required. More recent work has been shown that estrogen action in male reproductive system does not involve EREs pathway (Weiss et al. 2008). Moreover, many studies revealed a nongenomic signaling pathway through membrane-associated ERs (Hammes \& Levin 2007) and cross-talk between genomic pathways (Revelli et al. 1998, Losel et al. 2003). Binding of $\mathrm{E}_{2}$ to the membrane-associated ERs results in rapid (within minutes) activation of the MAP kinase, phosphatidylinositol 3-kinase, and protein kinase $\mathrm{C}$ and phosphatases, as well as the release of several cyclic amines 

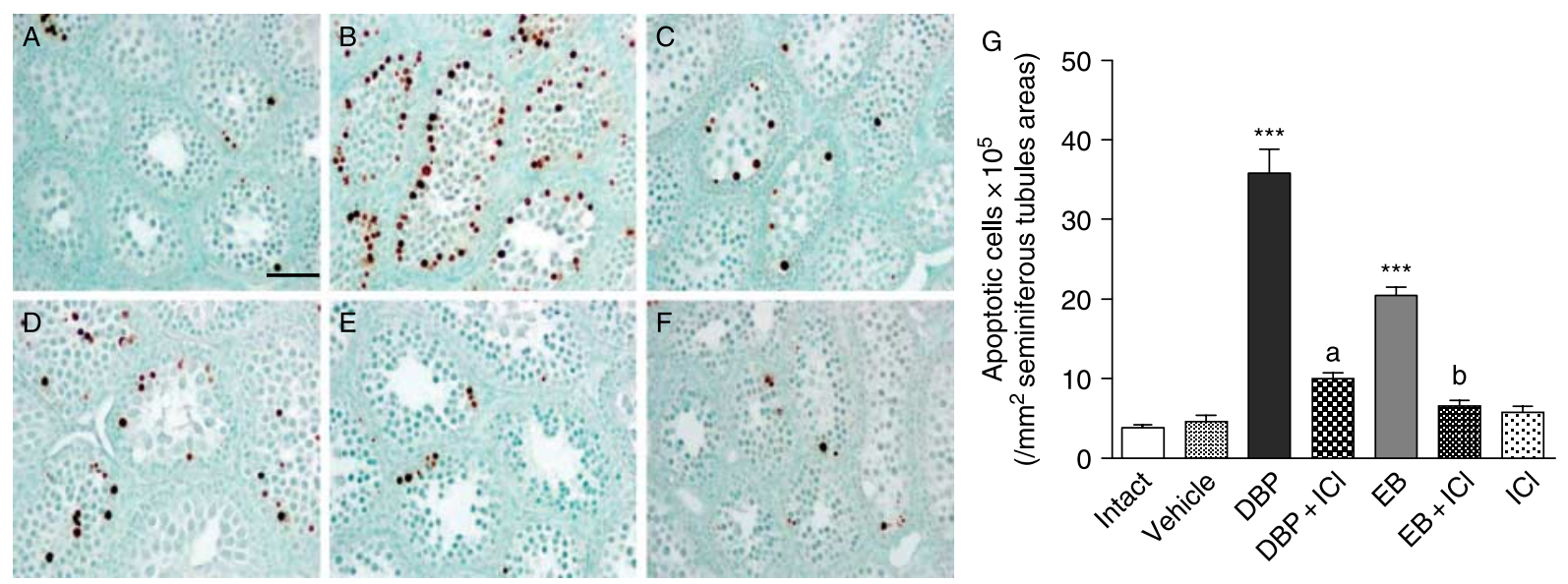

Figure $5 \mathrm{ICl}$ inhibits DBP- or EB-induced spermatogenic cell apoptosis. Results are shown for the control (A), DBPalone (B), DBP+ICl (C), EB alone (D), $\mathrm{EB}+\mathrm{ICI}(\mathrm{E})$, and $\mathrm{ICl}$ alone $(\mathrm{F})$ groups. Rats $(n=12)$ were i.p. administered with $3 \mathrm{mg} / \mathrm{kg}$ of $\mathrm{ICl}(5 \%$ ethanol and $95 \%$ corn oil) $4 \mathrm{~h}$ prior to administration of DBP or EB. The doses of DPB and EB were $500 \mathrm{mg} / \mathrm{kg}$ and $200 \mu \mathrm{g} / \mathrm{kg}$ respectively. Apoptotic spermatocytes are stained brown. Scale bar, $50 \mu \mathrm{m}$. Comparison of the numbers of TUNEL-positive cells in the testes of treated rats $(\mathrm{G})$. Note that the numbers of both DBP- and EB-induced apoptotic spermatocytes were decreased by ICI pretreatment. Values representing the number of apoptotic cells per $1 \mathrm{~mm}^{2}$ seminiferous tubules areas are expressed as the means \pm S.E.M. $(n=12)$. Statistically significant differences were determined by ANOVA followed by Fisher's PLSD test $\left({ }^{* * *} P<0.001\right.$ versus vehicle or intact; ${ }^{\text {a }} P<0.001$ versus $D B P ;{ }^{b} P<0.001$ versus $\left.E B\right)$.

(cAMP and cGMP) and calcium, in a variety of cell types (Losel et al. 2003, Levin 2005, Hammes \& Levin 2007). Membrane-associated ERs have been shown to prevent chemotherapy or radiation-induced apoptosis in MCF-7 cell (Razandi et al. 2000). Since the reduction in spermatogenic cell apoptosis by pretreatment with $\mathrm{ICl}$ was seen after $6 \mathrm{~h}$ of DBP or EB treatment in the present study, it is possible that the spermatogenic cell apoptosis induced by estrogenic compounds is at least partly mediated by this rapid nongenomic ERs signaling pathway.

\section{DBP-induced spermatogenic cell apoptosis is independent of testicular steroidogenesis}

The number of apoptotic cells was drastically decreased in the rats treated with $\mathrm{DBP}+\mathrm{ICl}$ or $\mathrm{EB}+\mathrm{ICl}$ compared with the number in the rats treated with DBP or EB alone. Since $\mathrm{ICl}$ can bind to both ER $\alpha$ and ER $\beta$ (Kuiper et al. 1998, Howell et al. 2000), the effects of DBP as well as EB on testes may be mediated by ERs that expressed in hypothalamus-pituitary, or possibly in testis. One of the novel findings of our study is that $\mathrm{ICl}$ can abolish the DBP- as well as the EB-induced spermatogenic cell apoptosis, but does not rescue the decreased ITT level and testicular steroidogenic enzyme mRNA expression (Fig. 6). Similarly, decreased level of serum FSH induced by DBP and EB was not restored by pretreatment with $\mathrm{ICI}$ (Fig. 7), indicating that $\mathrm{ICI}$ had no biological effect on hypothalamic level. The increased rate of spermatogenic cell apoptosis induced by DBP may not be due to the reduction in testicular testosterone level. In some cases, a lowered level of
ITT could maintain spermatogenesis. For example, Zirkin et al. (1989) demonstrated that an 80\% reduction in the ITT level from the control values was sufficient for the maintenance of quantitatively complete spermatogenesis. They have concluded that there is far more testosterone present within the testis of intact rats than is required for the maintenance of normal spermatogenesis. Therefore, no induction of apoptosis was detected in the DBP+ICl-treated animals in which the number of apoptotic spermatogenic cells was almost the same as that in the control animals, although the ITT level was still much lower (Fig. 6). Therefore, it is suggested that DBP-induced spermatogenic cell apoptosis is not due to ITT reduction, but may be mediated by ERs expressed in testes. The discrepant finding that $\mathrm{ICl}$ inhibited spermatogenic cell apoptosis but did not rescue the testicular steroidogenesis and serum $\mathrm{FSH}$ level reduced by DBP or EB can be explained that $\mathrm{ICI}$ does not cross the brain barrier and fails to block uptake of $\left[{ }^{3} \mathrm{H}\right]$-estradiol into the nuclei of hypothalamic cells (Wade et al. 1993, Howell et al. 2000). The current study that $\mathrm{ICl}$ abolished the DBP- or EB-induced apoptosis but could not restore testicular steroidogenesis and serum FSH level is well correlated with Wade et al. (1993), suggesting that it cannot penetrate across the blood-brain barrier and fails to block ERs in the hypothalamus.

In the present study, we demonstrated for the first time that estrogenic compound-induced spermatogenic cell apoptosis is not associated with testicular steroidogenesis and that ERs are directly involved in spermatogenic cell apoptosis. Indeed, ER $\alpha$ and ER $\beta$ are both present in rat spermatocytes and round spermatids 
(Saunders et al. 1998, Pelletier et al. 2000). Moreover, using an in vitro model with isolated spermatogenic cells, it has been reported that estrogen directly induces spermatogenic cell apoptosis by cytochrome $c$ release from mitochondria and FasL up-regulation (Mishra \& Shaha 2005). However, this apoptosis was inhibited by tamoxifen, an ER antagonist, indicating that an estrogen-induced change occurs through hormone receptor interaction in spermatogenic cells. Therefore, the present observations essentially suggest the possibility that the ERs present in testes, probably in spermatogenic cells, have a role in inducing spermatogenic cell apoptosis when binding to exogenous/ endogenous estrogenic compounds. However, a direct action of estrogen or estrogenic compounds on spermatogenic cell apoptosis via ERs has to be clarified in the future.
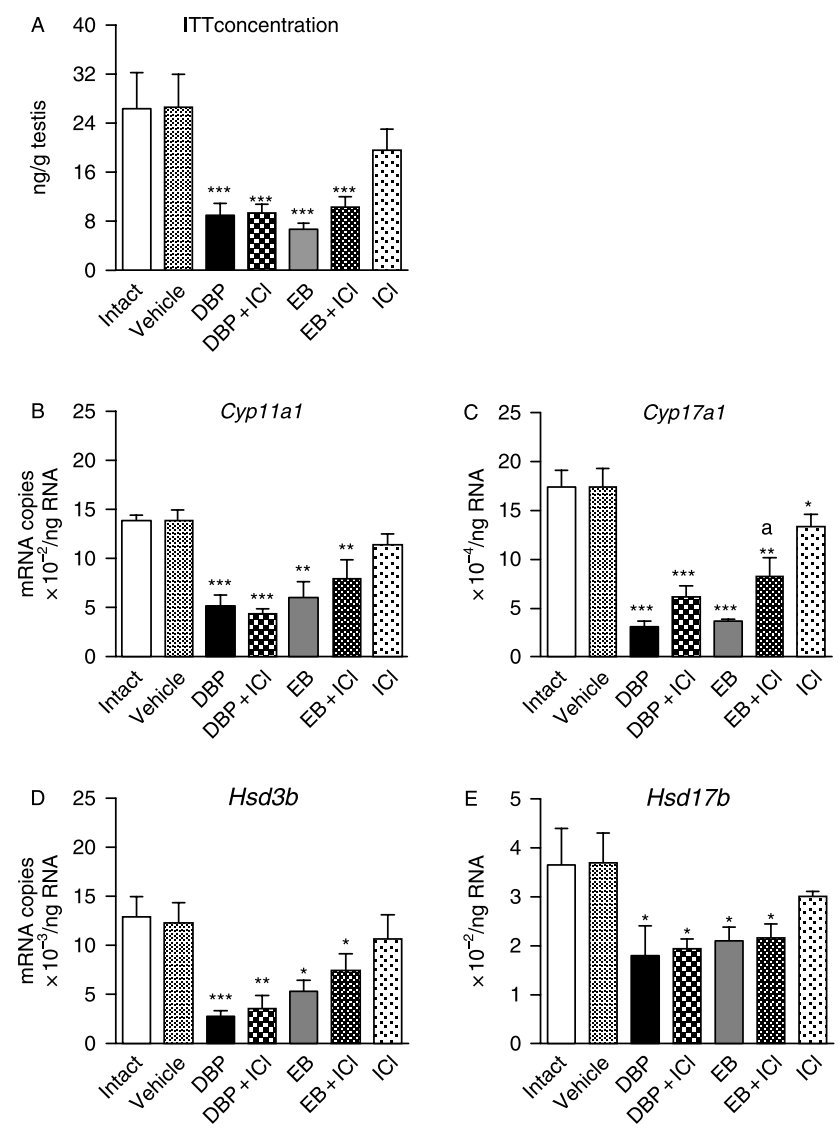

Figure 6 Comparison of ITT concentration and testicular steroidogenic enzyme gene expressions in the different treated groups. Intratesticular testosterone (ITT) level (A) and testicular mRNA expressions for Cyp11a1 (B), Cyp17a1 (C), Hsd3b (D), and Hsd17b (E). ITT level was measured by testosterone EIA assay, and mRNA expressions of testicular steroidogenic enzymes were analyzed by real-time RT-PCR. Results are represented as the means \pm S.E.M. ( $n=12$ for ITT and $n=9$ for testicular steroidogenic enzymes mRNA expressions). Statistically significant differences were determined by ANOVA followed by Fisher's PLSD test $\left({ }^{*} P<0.05\right.$; ${ }^{* *} P<0.01,{ }^{* * *} P<0.001$ versus vehicle or intact; ${ }^{a} P<0.05$ versus $\left.\mathrm{EB}\right)$.

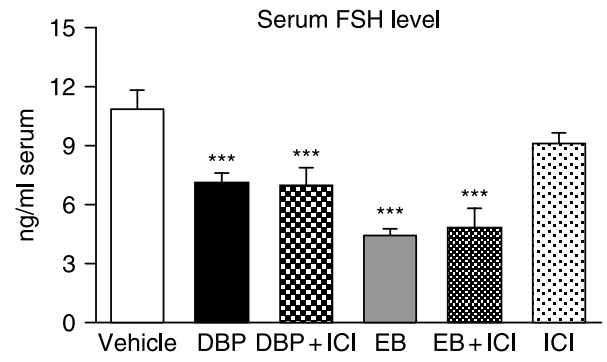

Figure 7 Serum FSH levels in the above inhibition study (Fig. 5) were measured by FSH ELISA assay. Results are represented as the means \pm S.E.M. $(n=9-12)$. Statistically significant differences were determined by ANOVA followed by Fisher's PLSD test $(* * * P<0.001$ versus vehicle).

In conclusion, this is the first report of estrogenic effects of DBP in vivo and essentially illustrates the possible role that ERs in testes play a role in spermatogenic cell apoptosis in response to environmental estrogenic compounds. We also demonstrated that testicular steroidogenesis was not associated with spermatogenic cell apoptosis induced by estrogenic compounds. Moreover, these data will be important for understanding the role of endogenous estrogen, which might induce spermatogenic cell apoptosis via ERs for the proper maintenance of normal testicular homeostasis.

\section{Materials and Methods}

\section{Chemicals}

DBP (purity $>99.8 \%$ ) and EB (purity $>99.0$ ) were purchased from Sigma-Aldrich. Antiestrogen ICI 182,780 was from Tocris Cookson, Ltd (Bristol, UK). Proteinase K and 3,3'-diaminobenzidine tetrahydrochloride were from TaKaRa (Otsu, Japan). Neutral buffer formalin and propylene oxide were from Wako (Osaka, Japan). Osmium tetroxide $\left(\mathrm{OsO}_{4}\right)$ and Araldite $\mathrm{M}$ were from Nisshin EM Co., Ltd (Tokyo, Japan). Testosterone EIA Kit was obtained from Cayman Chemical Company (Ann Arbor, MI, USA) and rat FSH ELISA kit from ALPCO Diagnostics (Windham, NH, USA). RNeasy Mini Kit was from Qiagen. TUNEL Kit, PrimeScript RT reagent Kit (Perfect Real Time), and Ex Taq polymerase with $10 \times$ Ex Taq buffer, SYBR Premix Ex Taq (Perfect Real Time) were purchased from TaKaRa.

\section{Animals and treatments}

Male Sprague-Dawley rats (3-week-old) were purchased from Charles River Laboratories Japan (Tokyo, Japan). The rats were housed five per one plastic cage, maintained on a $12 \mathrm{~h}$ light: $12 \mathrm{~h}$ darkness cycle at constant temperature $\left(22 \pm 1^{\circ} \mathrm{C}\right)$ and humidity $(45-70 \%)$, and provided water and rodent pellets (Oriental Yeast, Tokyo, Japan) ad libitum. Animals were maintained and handled humanely in accordance with the guidelines of the animal experiments of the Institutional Animal Care and Use Committee (IACUC) of the University of Tokyo, Tokyo, Japan. 
In the first experiment, 3-week-old male rats $(n=6)$ were given once daily by oral gavage for 7 days at the dose of 250 , 500 , or $1000 \mathrm{mg} / \mathrm{kg}$ DBP in mixture of $5 \%$ ethanol and $95 \%$ corn oil or vehicle (5\% ethanol and $95 \%$ corn oil). Rats were killed using diethyl ether on the day after completion of the treatment schedule, and testes were collected, weighed, and subjected to histopathology. In the second experiment, $500 \mathrm{mg} / \mathrm{kg}$ DBP as a representative dose was given to rats $(n=8)$ for 7 days in the same way as used in the first experiment. Testes were collected on the day after completion of the treatment schedule for ultrastructural observations of Leydig cells by transmission electron microscopy and analysis of testicular steroidogenesis using a Testosterone EIA Kit and real-time RT-PCR. In the third experiment, an acute DBP exposure study, rats $(n=8)$ were given a single exposure of DBP $(500 \mathrm{mg} / \mathrm{kg})$ or vehicle by oral gavage and killed at 3, 6, or $24 \mathrm{~h}$ after administration. Then, testes and sera were collected. In the last experiment, an inhibition study with pure antiestrogen, rats $(n=12)$ were i.p. administered with $3 \mathrm{mg} / \mathrm{kg} \mathrm{ICl}$ (5\% ethanol and 95\% corn oil) $4 \mathrm{~h}$ prior to administration of DBP or EB.

The chosen dose of DBP $(500 \mathrm{mg} / \mathrm{kg}$ ) was based on previous reports that adverse effects on male reproductive development occur between 100 and $500 \mathrm{mg} \mathrm{DBP} / \mathrm{kg}$ per day without systemic toxicity (Mylchreest et al. 2002). And the dosage of $\mathrm{ICl}$ was $3 \mathrm{mg} / \mathrm{kg}$ based on the previous study in which $1.5 \mathrm{mg} / \mathrm{kg}$ dosage was found to be effective estrogen antagonism (Sibonga et al. 1998).

\section{Histopathology}

For histopathological observations with hematoxylin and eosin or TUNEL staining, testes were immersed in $10 \%$ neutrally buffered formalin for $48 \mathrm{~h}$ at room temperature. Then, the samples were washed in $0.1 \mathrm{M}$ PBS for $3 \mathrm{~h}$, dehydrated through a graded series of ethanol, cleared in xylene, and embedded in paraffin. The paraffin blocks were cut at $4 \mu \mathrm{m}$ thickness. For transmission electron microscopy, rats were perfused with $5 \%$ glutaraldehyde in $0.1 \mathrm{M}$ phosphate buffer, and then testes were immersed in the same fixative at $4{ }^{\circ} \mathrm{C}$ for $3 \mathrm{~h}$ and postfixed in $1 \% \mathrm{OsO}_{4}$ at $4{ }^{\circ} \mathrm{C}$ for $2 \mathrm{~h}$. The samples were then dehydrated in ethanol, infiltrated in propylene oxide, and embedded in Araldite M. Semi-thin sections were cut at $1 \mu \mathrm{m}$ thickness, stained with $1 \%$ toluidine blue, and observed by light microscopy. Ultrathin sections were cut, stained with uranyl acetate and lead citrate, and examined with a JEM-1010 transmission electron microscope at $80 \mathrm{kV}$ (JEOL, Ltd, Tokyo, Japan).

\section{TUNEL assay}

In order to quantitatively assess the incidence of apoptotic spermatogenic cells after treatment, in situ TUNEL was performed by using an Apoptotic Detection Kit according to the manufacturer's instructions. Briefly, the tissue sections were deparaffinized and digested with $10 \mu \mathrm{g} / \mathrm{ml}$ proteinase $\mathrm{K}$ at $37^{\circ} \mathrm{C}$ for $15 \mathrm{~min}$. After being washed three to five times with $0.01 \mathrm{M}$ PBS $(\mathrm{pH} 7.4)$, they were treated with terminal deoxynucleotidyl transferase (TdT) enzyme and labeling safe buffer, which were included in the kit. The TdT reaction was conducted at $37^{\circ} \mathrm{C}$ for $90 \mathrm{~min}$. After further washing three to five times with PBS, they were incubated with HRP goat anti-biotin at $37^{\circ} \mathrm{C}$ for $30 \mathrm{~min}$. The localization of HRP sites was determined by the application of diaminobenzidine. The sections were then counterstained with methyl green and mounted. Images of seminiferous tubules were obtained by using an OLYMPUS (BX50) light microscope connected to a digital camera (OLYMPUS, DP20, Tokyo, Japan). Under the microscope at $200 \times$ magnification, three fields in each section were randomly selected. The area of seminiferous tubules in all fields was measured by a computer-assisted system using Scion Image software (Scion Co., Frederick, MD, USA). Then, TUNEL-positive (brown-stained) spermatogenic cells in all selected area were counted. The number of TUNEL-positive cells per $1 \mathrm{~mm}^{2}$ seminiferous tubules was calculated by dividing the total TUNEL-positive cell numbers by total seminiferous tubules area of each field and calculated accordingly in all of the fields. Data were obtained from 8-12 rats in each group and were given as mean \pm S.E.M.

\section{Hormone assay}

The concentration of ITT was determined by using a Testosterone EIA Kit as previously described (Ohsako et al. 2003). To measure the concentration of ITT, the frozen testis was thawed and homogenized in PBS with a Polytron homogenizer (Kinematica, Luzern, Switzerland), and the testicular homogenate was extracted twice with an appropriate volume of diethyl ether. ITT level was measured according to the manufacturer's protocol. Serum LH concentration was analyzed by double antibody RIA, using materials supplied by the National Institute of Diabetes and Digestive and Kidney Diseases (NIDDK). The reference standard for the $\mathrm{LH}$ assay was NIDDK-rLH-rp-3. The intra- and inter-assay coefficients of variation (CV) for the LH assays, which were calculated from five to seven replicated determinations for the

Table 1 Primers used for real-time quantitative RT-PCR.

\begin{tabular}{|c|c|c|c|c|}
\hline \multirow[b]{2}{*}{ Gene } & \multicolumn{2}{|c|}{ Primer sequences } & \multirow{2}{*}{$\begin{array}{l}\text { Product } \\
\text { size (bp) }\end{array}$} & \multirow[b]{2}{*}{ Gene ID } \\
\hline & Forward (genomic position) & Reverse (genomic position) & & \\
\hline Cyp11a1 & TGAGATCCСTTCCСCTGGTG (exon 1) & TCGCTGCGTCCTTAGGGTC (exon 2) & 179 & J05156 \\
\hline Сур17a1 & GGTCCCATCTATTCTCTTCGC (exon 1) & CTGAACACCAACTTCCGGT (exon 2) & 209 & M22204 \\
\hline$H s d 3 b$ & CTCTGGACAAAGTCTTCAGACCAGA (exon 2) & GCCTGGGTAGGACATGTGAGAC (exon 3) & 183 & M38178 \\
\hline$H s d 17 b$ & GGTTCTCCCGGTACCTTTTT (exon 1) & GTCCGGCTGATAAGTACAACA (exon 3) & 166 & AF035156 \\
\hline Ppia & GGTCCTGGCATCTTGTCCATC (exon 4) & TTCCACAATGCTCATGCCTT (exon 5) & 141 & M19533 \\
\hline
\end{tabular}


pool of rat serum containing $3.0 \mathrm{ng} / \mathrm{ml}$ of $\mathrm{LH}$, were 6.8 and $7.1 \%$ respectively. The serum FSH levels were determined using a rat-specific FSH ELISA kit, 29-AER004, from ALPCO Diagnostics. The manufacturer has validated this kit for the measurement of FSH in rat serum samples. The FSH assays were carried out according to the manufacturer's protocol. The sensitivity of the assay was $0.2 \mathrm{ng} / \mathrm{ml}$. The kit was highly specific for rat FSH, with $<0.1 \%$ cross-reactivity to rat $\mathrm{GH}, \mathrm{LH}$, $\mathrm{TSH}$, and PRL. The intra- and inter- assay CV were 4.73 and $8.47 \%$ respectively.

\section{Real-time RT-PCR}

Total RNAs were extracted from testes by using an RNeasy Mini Kit (Qiagen). Four micrograms of total RNA samples were reverse-transcribed by using a PrimeScript RT reagent Kit (Perfect Real Time) according to the standard protocol of the supplier. Real-time PCR was performed by using SYBR Premix Ex Taq and a Light Cycler rapid thermal cycler system (Roche Molecular Systems). Table 1 shows the primer sequences, PCR product sizes, and GenBank accession numbers for all genes examined in this study - i.e. the genes encoding cytochrome P450 side chain cleavage (P450sCC, Cyp11a1), cytochrome P450 17a/C $C_{17-20}$ lyase (P450c17, Cyp17a1), Hsd3b, Hsd17b, and cyclophilin-A (Cp, Ppia). The denaturation step was performed at $95^{\circ} \mathrm{C}$ for $15 \mathrm{~min}$, and the PCR was carried out in separate glass capillary tubes over 40 cycles $\left(95^{\circ} \mathrm{C}\right.$ for $15 \mathrm{~s}$, $60{ }^{\circ} \mathrm{C}$ for $20 \mathrm{~s}$, and $72{ }^{\circ} \mathrm{C}$ for $10 \mathrm{~s}$ ). Detection of fluorescent products was carried out at the end of the $72{ }^{\circ} \mathrm{C}$ extension period. The copy numbers of target mRNA molecules in each total RNA sample were determined by the original methods as described previously (Sakata et al. 2007). The mRNA levels were expressed as copy number per ng total RNA.

\section{Statistical analysis}

Statistical analysis was performed using StatView software (SAS Institute Inc., Cary, NC, USA). All results are represented as the means \pm S.E.M. For the comparison of testis weight, apoptotic spermatogenic cell index, serum LH, serum FSH, testicular testosterone levels, and steroidogenic enzyme gene expression levels in the dose response, time-course and inhibition studies, one-way ANOVA were carried out followed by Fisher's PLSD as a post hoc test. Two-tailed Student's $t$-test was used to compare the mean values of the ITT and testicular steroidogenic enzyme gene expression obtained in the repeated DBP exposure study. Differences were considered to be statistically significant when the $P$ value was $<0.05$. Significant differences between each group are indicated in the figures where detected.

\section{Declaration of interest}

The authors declare that there is no conflict of interest that could be perceived as prejudicing the impartiality of the research reported.

\section{Funding}

This work was supported in part by Grants-in-Aid from the Ministry of Education, Science, Sports, and Culture, Japan (to M Kurohmaru), and also supported by the Environmental Technology Development (to S Ohsako and H Sone) from the Ministry of the Environment, Japan.

\section{References}

Akingbemi BT \& Hardy MP 2001 Oestrogenic and antiandrogenic chemicals in the environment: effects on male reproductive health. Annals of Medicine 33 391-403.

Andersen HR, Andersson AM, Arnold SF, Autrup H, Barfoed M, Beresford NA, Bjerregaard P, Christiansen LB, Gissel B, Hummel R et al. 1999 Comparison of short-term estrogenicity tests for identification of hormone-disrupting chemicals. Environmental Health Perspectives 107 89-108.

Blanco-Rodriguez J \& Martinez-Garcia C 1997 Apoptosis pattern elicited by oestradiol treatment of the seminiferous epithelium of the adult rat. Journal of Reproduction and Fertility 110 61-70.

Blanco-Rodriguez J \& Martinez-Garcia C 1998 Apoptosis precedes detachment of germ cells from the seminiferous epithelium after hormone suppression by short-term oestradiol treatment of rats. International Journal of Andrology 21 109-115.

Colon I, Caro D, Bourdony J \& Rosario O 2000 Identification of phthalate esters in the serum of young Puerto Rican girls with premature breast development. Environmental Health Perspectives 108 895-900.

Creasy DM 2001 Pathogenesis of male reproductive toxicity. Toxicologic Pathology 29 64-76.

D'Souza R, Gill-Sharma MK, Pathak S, Kedia N, Kumar R \& Balasinor N 2005 Effect of high intratesticular estrogen on the seminiferous epithelium in adult male rats. Molecular and Cellular Endocrinology 241 41-48.

Eddy EM, Washburn TF, Bunch DO, Goulding EH, Gladen BC, Lubahn DB \& Korach KS 1996 Targeted disruption of the estrogen receptor gene in male mice causes alteration of spermatogenesis and infertility. Endocrinology 137 4796-4805.

Fukuoka M, Zhou Y, Tanaka A, Ikemoto I \& Machida T 1990 Mechanism of testicular atrophy induced by di- $n$-butyl phthalate in rats. Part 2 . The effects on some testicular enzymes. Journal of Applied Toxicology $\mathbf{1 0}$ 285-293.

Gray TJ, Rowland IR, Foster PM \& Gangolli SD 1982 Species differences in the testicular toxicity of phthalate esters. Toxicology Letters 11 141-147.

Hall JM \& Korach KS 2002 Analysis of the molecular mechanisms of human estrogen receptors alpha and beta reveals differential specificity in target promoter regulation by xenoestrogens. Journal of Biological Chemistry 277 44455-44461.

Hammes SR \& Levin ER 2007 Extranuclear steroid receptors: nature and actions. Endocrine Reviews 28 726-741.

Harris CA, Henttu P, Parker MG \& Sumpter JP 1997 The estrogenic activity of phthalate esters in vitro. Environmental Health Perspectives 105 802-811.

Hong EJ, Ji YK, Choi KC, Manabe N \& Jeung EB 2005 Conflict of estrogenic activity by various phthalates between in vitro and in vivo models related to the expression of Calbindin-D9k. Journal of Reproduction and Development 51 253-263.

Howell A, Osborne CK, Morris C \& Wakeling AE $2000 \mathrm{ICl} 182,780$ (Faslodex): development of a novel, "pure" antiestrogen. Cancer 89 $817-825$.

Jobling S, Reynolds T, White R, Parker MG \& Sumpter JP 1995 A variety of environmentally persistent chemicals, including some phthalate plasticizers, are weakly estrogenic. Environmental Health Perspectives $103582-587$.

Jong FH, Uilenbroek J \& Van der Molen HJ 1975 Oestradiol-17 $\beta$, testosterone and gonadotrophins in oestradiol-17 $\beta$-treated intact adult male rats. Journal of Endocrinology 65 281-282.

Kim IY, Han SY \& Moon A 2004 Phthalates inhibit tamoxifen-induced apoptosis in MCF-7 human breast cancer cells. Journal of Toxicology and Environmental Health 67 2025-2035. 
Kleymenova E, Swanson C, Boekelheide K \& Gaido KW 2005 Exposure in utero to di(n-butyl) phthalate alters the vimentin cytoskeleton of fetal rat Sertoli cells and disrupts Sertoli cell-gonocyte contact. Biology of Reproduction 73 482-490.

Kuiper GG, Shughrue PJ, Merchenthaler I \& Gustafsson JA 1998 The estrogen receptor beta subtype: a novel mediator of estrogen action in neuroendocrine systems. Frontiers in Neuroendocrinology 19 253-286.

Levin ER 2005 Integration of the extra-nuclear and nuclear actions of estrogen. Molecular Endocrinology 19 1951-1959.

Losel RM, Falenstein E, Feuring $M$, Schultz A, Tillmann HC, Rossol-Haseroth K \& Wehling M 2003 Nongenomic steroid action: controversies, questions, and answers. Physiological Reviews 83 965-1016.

McEwen BS \& Alves SE 1999 Estrogen actions in the central nervous system. Endocrine Reviews 20 279-307.

McGarvey C, Cates PA, Brooks A, Swanson IA, Milligan SR, Coen CW \& O'Byrne KT 2001 Phytoestrogens and gonadotropin-releasing hormone pulse generator activity and pituitary luteinizing hormone release in the rat. Endocrinology 142 1202-1208.

McLachlan RI, O'Donnell L, Meachem SJ, Stanton PG, de Kretser DM, Pratis K \& Robertson DM 2002 Identification of specific sites of hormonal regulation in spermatogenesis in rats, monkeys, and man. Recent Progress in Hormone Research 57 149-179.

Milligan SR, Balasubramanian AV \& Kalita JC 1998 Relative potency of xenobiotic estrogens in an acute in vivo mammalian assay. Environmental Health Perspectives 106 23-26.

Mishra DP \& Shaha C 2005 Estrogen-induced spermatogenic cell apoptosis occurs via the mitochondrial pathway: role of superoxide and nitric oxide. Journal of Biological Chemistry $2806181-6196$.

Mylchreest E, Sar M, Wallace DG \& Foster PM 2002 Fetal testosterone insufficiency and abnormal proliferation of Leydig cells and gonocytes in rats exposed to di(n-butyl) phthalate. Reproductive Toxicology 16 19-28.

Nishihara T, Nishikawa J, Kanayama T, Dakeyama F, Saito K, Imagawa M, Takatori M, Kitagawa Y, Hori S \& Utsumi H 2000 Estrogenic activities of 517 chemicals by yeast two-hybrid assay. Journal of Health Science 46 282-198.

Nonclercq D, Reverse D, Toubeau G, Beckers JF, Sulon J, Laurent G, Zanen J \& Heuson-Stiennon JA 1996 In situ demonstration of germinal cell apoptosis during diethylstilbestrol-induced testis regression in adult male Syrian hamsters. Biology of Reproduction 55 1368-1376.

O'Donnell L, Robertson KM, Jones ME \& Simpson ER 2001 Estrogen and spermatogenesis. Endocrine Reviews 22 289-318.

Ohsako S, Kubota K, Kurosawa S, Takeda K, Qing W, Ishimura R \& Tohyama C 2003 Alterations of gene expression in adult male rat testis and pituitary shortly after subacute administration of the antiandrogen flutamide. Journal of Reproduction and Development 49 275-290.

Oishi S \& Hiraga K 1980 Testicular atrophy induced by phthalic acid monoesters: effects of zinc and testosterone concentrations. Toxicology 15 197-202.

Paech K, Webb P, Keiper GG, Nilsson S, Gustafsson J, Kushner PJ \& Scanlan TS 1997 Differential ligand activation of estrogen receptors ERalpha and ERbeta at AP1 sites. Science 277 1508-1510.

Pelletier G, Labrie C \& Labrie F 2000 Localization of oestrogen receptor alpha, oestrogen receptor beta and androgen receptors in the rat reproductive organs. Journal of Endocrinology 165 359-370.

Razandi M, Pedram A \& Levin ER 2000 Plasma membrane estrogen receptors signal to antiapoptosis in breast cancer. Molecular Endocrinology 14 1434-1447.
Revelli A, Massobrio M \& Tesarik J 1998 Nongenomic actions of steroid hormones in reproductive tissues. Endocrine Reviews 19 3-17.

Ryu JY, Lee BM, Kacew S \& Kim HS 2007 Identification of differentially expressed genes in the testis of Sprague-Dawley rats treated with di(n-butyl) phthalate. Toxicology 234 103-112.

Sakata Y, Yoshioka W, Tohyama C \& Ohsako S 2007 Internal genomic sequence of human CYP1A1 gene is involved in superinduction of dioxin-induced CYP1A1 transcription by cycloheximide. Biochemical and Biophysical Research Communications 355 687-692.

Saunders PT, Fisher JS, Sharpe RM \& Millar MR 1998 Expression of oestrogen receptor beta (ER beta) occurs in multiple cell types, including some germ cells, in the rat testis. Journal of Endocrinology 156 13-17.

Saunders PT, Millar MR, Macpherson S, Irvine S, Groome NP, Evans LR, Sharpe RM \& Scobie GA 2002 ERbeta1 and the ERbeta2 splice variant (ERbetacx/beta2) are expressed in distinct cell populations in the adult human testis. Journal of Clinical Endocrinology and Metabolism 87 2706-2715.

Sibonga JW, Dobning H, Harden RM \& Turner RT 1998 Effect of the high-affinity estrogen receptor ligand $\mathrm{ICI} 182,780$ on the rat tibia. Endocrinology 139 3736-3742.

Soto AM, Sonnenschein C, Chung KL, Fernandez MF, Olea N \& Serrano FO 1995 The E-SCREEN assay as a tool to identify estrogens: an update on estrogenic environmental pollutants. Environmental Health Perspectives 103 113-122.

Tena-Sempere M, Navarro J, Pinilla L, Gonzalez LC, Huhtaniemi I \& Aguilar E 2000 Neonatal exposure to estrogen differentially alters estrogen receptor alpha and beta mRNA expression in rat testis during postnatal development. Journal of Endocrinology 165 345-357.

Wade GN, Blaustein JD, Gray JM \& Meredith JM 1993 ICI182,780: a pure antiestrogen that affects behaviors and energy balance in rats without acting in the brain. American Journal of Physiology 265 1392-1398.

Weiss J, Bernhardt ML, Laronda MM, Hurley LL, Glidewell-Kenney C, Pillai S, Tong M, Korach KS \& Jameson JL 2008 Estrogen actions in the male reproductive system involve estrogen response elementindependent pathways. Endocrinology 149 6198-6206.

Wiebe VJ, Osborne CK, Fuqua SA \& DeGregorio MW 1993 Tamoxifen resistance in breast cancer. Critical Reviews in Oncology/Hematology 14 173-188.

Zacharewski TR, Meek MD, Clemons JH, Wu ZF, Fielden MR \& Matthews JB 1998 Examination of the in vitro and in vivo estrogenic activities of eight commercial phthalate esters. Toxicological Sciences 46 282-293.

Zirkin BR, Santulli R, Awoniyi CA \& Ewing LL 1989 Maintenance of advanced spermatogenic cells in the adult rat testis: quantitative relationship to testosterone concentration within the testis. Endocrinology 124 3043-3049.

Received 3 June 2009

First decision 23 July 2009

Revised manuscript received 1 October 2009

Accepted 10 November 2009 